DOI: $10.1515 / \mathrm{rpp}-2015-0066$

$\mathrm{PhD}$ in Pedagogical Sciences, Associate Professor, IHOR BLOSHCHYNSKYI Bohdan Khmelnytskyi National Academy of the State Border Guard Service of Ukraine Address: 46 Shevchenko St., Khmelnytskyi, 29003 Ukraine E-mail:i.bloshch@gmail.com

\title{
PECULIARITIES OF US BORDER GUARD OFFICERS' TRAINING AT THE FEDERAL LAW ENFORCEMENT TRAINING CENTER USING ONLINE CAMPUS
}

\begin{abstract}
Professional training of future US border guard officers at the Federal Law Enforcement Training Center using e-FLETC Online Campus has been substantiated in the article. Special attention has been paid to revealing such topical areas of Online Campus computer-based training modules (crime scene, driver training, drugs, firearms, health, interviewing, investigative, legal, mapping, maritime, officer safety, technology, terrorism, traffic stops, training) that include over 120 lessons and 20 videos which are available on a wide range of topics. Web-based training lessons which include topics such as counterterrorism, crime scene preservation and documentation, disaster, crisis and emergency strategies and management, domestic violence, drug endangered children, drug related crimes, elder abuse, firearms, fitness and healthy lifestyles, human trafficking, interacting with special needs populations, intelligence led policing, interpersonal skills and conflict management, interviews and interrogations, investigating technology related crimes (protecting and collecting digital evidence), investigative skills and techniques, knowledge of laws and regulations, leadership and management, lessons learned (previous case analysis), maritime law enforcement, etc. have been revealed. Besides, examples of "Firearms" and "Use of Force" curricula in e-FLETC Online Campus have been presented.

Key words: border guard officers, distance learning, US Federal Law Enforcement Training Center, Online Campus.

\section{INTRODUCTION}

Training of future border guard officers is aimed at forming the integral personality, purposeful identification and development of person's skills and desire to lifelong learning. In this context distance learning (DL) technologies in higher military establishment will facilitate the forming and development of future border guard officers' abilities to independentsearching, solving non-standard creative tasks, modeling of own activities. Border agencies of the world use different Internet (Intranet) platforms or (Online Campuses) for personnel training. Learning platform MOODLE is used in the State Border Guard Service of Ukraine (SBGSU) for DL of personnel. Therefore, foreign countries expierence study of future border guard officers' training with the use of specialized educational platforms (learning campus/portals), namely, US border guard officers is quite topical.
\end{abstract}

\section{THE AIM OF THE STUDY}

The aim of the study is to substantiate the professional training of future US border guard officers at the Federal Law Enforcement Training Center using e-FLETC Online Campus. 


\section{THEORETICAL FRAMEWORK AND RESEARCH METHODS}

The foreign training experience in US educational establishments is investigated in the works of such domestic and foreign scholars: (Y. Komkova, A. Kuzminskyi, A. Nekrasov, R. Sharan, B Shunevych and others). The USA is a country with long experience of law enforcement system reforming, that is why the present requirements resulted in the creation of specialized educational information portals and learning platforms for law enforcement personnel training. Scientific studies considering peculiarities of border guard officers' professional training using Internet-platforms (online learning centers) in modern pedagogical science do not receive proper attention.

To achieve the purpose of the study the whole complex of research methods was used, namely, theoretical methods of analysis, synthesis, generalization, systematization of theoretical and practical material of the research.

\section{RESULTS}

International cooperation among border agencies is at a new stage of development due to increased scale of illegal migration, smuggling of weapons and goods, human trafficking and other forms of transborder crime. SBGSU cooperation experience with the US government on border guard officers' training deserves particular attention. As a result, six projects considering international technical assistance in the sphere of preventing the spread of nuclear and other radioactive materials, weapons of mass destruction (WMD) in the framework of programs "Second Line of Defence", "Non-Proliferation of WMD" had been implemented by 2015 . This gave an opportunity to get modern radiation monitoring system (radiation monitoring devices, technical means of border control, automotive equipment) and test complexes of nuclear and radioactive materials detection; increase the potential of border guard divisions at the state border and in the Chernobyl zone of Ukraine-Russia border areas; equip educational establishments of SBGSU with means of protection and portable radiation monitoring devices.

Investigations of the late 1960's presented a need for high-quality and costeffective training of US Federal law enforcement agents by professional instructors using modern training facilities. Therefore, in 1975, after review of existing facilities, the former Glynco Naval Air Station near Brunswick, Georgia, was selected. Later it was renamed into Federal Law Enforcement Training Center (FLETC). Glynco is the headquarters site and main campus for the FLETC, which includes facilities in Artesia, (New Mexico), Charleston, (South Carolina), and Cheltenham, (Maryland), and Gabarone, Botswana (FLETC History, 2015). FLETC formally transferred from the Treasury Department to the newly created Department of Homeland Security (DHS) in 2003. The major components that make up the DHS are Office of the Secretary, Border and Transportation Security, Emergency Preparedness and Response, Information Analysis and Infrastructure Protection, Science and Technology, Office of Management, US Citizenship and Immigration Services, Coast Guard and US Secret Service (Блощинський, Гапонова, Яремчук, 2006).

Border and Transportation Security (BTS) Directorate secures borders and transportation systems and enforces the US immigration laws. BTS includes Transportation Security Administration, Customs and Border Protection (CBP), Immigration and Customs Enforcement. BTS oversees all aspects of border control, includes visa policies, immigration and transportation policies within and outside of US in terms of portage of materials, entry/exit from bordering countries, etc. (Блощинський, Гапонова, Яремчук, 2006). The CBP Officer Basic Training Academy is located at the (FLETC) in Glynco, Georgia. The 89-day program is focused on operational effectiveness, enhanced enforcement tools and 
tactics and building capacities as to ensure border security and prevent terrorism. CBP officer training includes 105 hours of practical exercise training, classroom time and interactive scenarios. New trainees must pass 7 practical exercise tests, 8 written examinations and 23 graded practical exercises (Federal Law Enforcement Resources, 2015).

All new border guard officers receive training at the CBP Border Patrol Academy in Artesia, New Mexico. Once a person is accepted into the academy he/she will spend 58 days learning both federal law enforcement and border patrol subjects in order to be ready for performing such border patrol operations, namely linewatch and signcutting, traffic checks, transportation checks, air operations, marine patrol, horse and bike patrol and drug seizures (Блощинський, Гапонова, Яремчук, 2006). To start a border patrol career a person must be under the age of 40, have US citizenship, able to learn Spanish and pass a thorough medical examination (Official website of the DHS, 2015).

The curriculum at the Border Patrol Academy is divided into five areas such as academy law, firearms training, physical techniques, driver training, Spanish-based language training program (Border Patrol Academy: Courses and Curriculum, 2015). However, with recurring budget cuts and a growing demand for training, the agency began to investigate the potential of DL. A pilot program was implemented in 2002. Today, the DL Program gives officers access to more than 1,700 courses in business skills, management, communication and technology, as well as 35 custom courses in highly specific areas such as electronic crime, DNA, vehicle searches and roadblocks. The agency has developed HTML templates and an electronic support system to assist subject-matter experts in developing Web-based material. FLETC's customs content is increasing by as many as 200 curriculum hours each year. The FLETCs, DHS Information Network and Blackboard Learn have recently partnered to build an Online Campus with the goal of training federal law enforcement officers all across the country. By the end of the second quarter fiscal year 2015, they will have had 102 computer-based training modules posted on the HSIN network, in the below listed topical areas. This will provide invaluable training with final module test and FLETC certificates of completion (Official Website of the DHS, 2015).

The topical areas of online campus computer-based training modules are crime scene ( 9 modules), driver training ( 2 modules), drugs (1 module), firearms (4 modules), health (10 modules), interviewing ( 2 modules), investigative (21 modules), legal (25 modules), mapping ( 7 modules), maritime (4 modules), officer safety (4 modules), technology (6 modules), terrorism ( 1 module), traffic stops (1 module), training (4 modules). The FLETC's Online Campus is a secure site that is open 24 hours a day, 7 days a week and provides training intended only for law enforcement officers and, in some cases, individuals who serve in supporting roles. All individuals who register are properly vetted before they are given access to the training. This campus is a dynamic environment that is why lessons are continually reviewed to ensure their accuracy currency and relevance to the officers' needs. Additionally, new lessons are added on an ongoing basis. There are over 120 lessons and 20 videos available on a wide range of topics including forensics, interviewing techniques, intelligence-led policing, leadership and management and digital evidence techniques (Federal Law Enforcement Training Center, 2015).

Web-based training lessons include counterterrorism, crime scene preservation and documentation, disaster, crisis and emergency strategies and management, domestic violence, drug endangered children, drug related crimes, elder abuse, firearms, fitness and healthy lifestyles, human trafficking, interacting with special needs populations, intelligence-led policing, interpersonal skills and conflict management, interviews and interrogations, investigating technology related crimes / protecting and collecting digital evidence, 
investigative skills and techniques, knowledge of laws and regulations, leadership and management, lessons learned / previous case analysis, maritime law enforcement (e-FLETC Online Campus, 2015). Here are some examples of "Firearms" and "Use of Force" curricula in e-FLETC Online Campus (Table 1) (Federal Law Enforcement Training Center, 2015).

Table 1

Curricula of "Firearms" and "Use of Force" Courses in e-FLETC Online Campus

\begin{tabular}{|c|c|c|}
\hline \multicolumn{3}{|c|}{ Firearms } \\
\hline Title & Course Description & Course Length \\
\hline \begin{tabular}{c|} 
Firearms \\
Safety Rules \\
and Regulations
\end{tabular} & $\begin{array}{l}\text { This course was developed to indoctrinate all firearms students to } \\
\text { the FLETC Firearms Safety Rules and Regulations prior to their } \\
\text { participation in any live fire range exercise }\end{array}$ & $\begin{array}{l}1 \text { hour } \\
30 \text { minutes }\end{array}$ \\
\hline $\begin{array}{l}\text { Firearms Range } \\
\text { Safety }\end{array}$ & $\begin{array}{l}\text { Teaching students to recognize safety violations that could result } \\
\text { in serious or fatal injuries. Additionally, students will demonstrate } \\
\text { safe weapons handling procedures with various weapons systems } \\
\text { during the designated program and also they will be required to } \\
\text { identify pertinent safety equipment, as well as recognize and correct } \\
\text { any safety hazards encountered in a firearms range environment }\end{array}$ & $\begin{array}{l}1 \text { hour } \\
30 \text { minutes }\end{array}$ \\
\hline Off Range Safety & $\begin{array}{l}\text { This course was developed to provide students with a review of } \\
\text { firearms safety they have encountered during lecture, laboratory } \\
\text { and practical exercises involving weapons }\end{array}$ & 45 minutes \\
\hline $\begin{array}{l}\text { Remington } \\
\text { Model } 870 \\
\text { Shotgun Video }\end{array}$ & $\begin{array}{l}\text { An instructor demonstrates proper safety, disassembly, reassembly } \\
\text { and reloading procedures for the Remington Model } 870 \text { Shotgun }\end{array}$ & $101 / 2$ minutes \\
\hline $\begin{array}{l}\text { Trauma } \\
\text { Management } \\
\text { on the Range }\end{array}$ & $\begin{array}{l}\text { This course covers the prevention and recognition of injuries or } \\
\text { illnesses that can be encountered on the range during firearms- } \\
\text { related training. It also provides directions for basic first aid that } \\
\text { may be required on the range }\end{array}$ & 45 minutes \\
\hline \multicolumn{3}{|c|}{ Use of Force } \\
\hline $\begin{array}{l}\text { Legal Aspects } \\
\text { of Taser Video }\end{array}$ & Federal law enforcement instructors discuss the use of TASERS & $\begin{array}{l}1 \text { hour } 10 \\
\text { minutes }\end{array}$ \\
\hline POC Spray & $\begin{array}{l}\text { This course is designed to provide students with the information } \\
\text { relating to the methods and techniques, to properly handle and } \\
\text { administer first aid and post-care treatment, during the arrest } \\
\text { and/or transport of person(s) exposed to the inflammatory agent } \\
\text { Oleoresin Capsicum }\end{array}$ & 1 hour \\
\hline $\begin{array}{l}\text { Criminals on } \\
\text { a Short Leash }\end{array}$ & The advantages of using police dogs are discussed in this video & 1 hour \\
\hline Use of Force & $\begin{array}{l}\text { Providing future officers with a better understanding of the } \\
\text { Constitutional requirements in the use of force. Law enforcement } \\
\text { officers need to be proficient in knowing when not to use force, } \\
\text { as well as be effective in employing force. They also need to fully } \\
\text { understand it is acceptable to do so }\end{array}$ & 3 hours \\
\hline
\end{tabular}

Special attention for border guard officers is paid to Human Trafficking Training Program (DL course) which provides a series of scenarios that depict indicators of human trafficking. The Operational Skills Laboratories allow students to incorporate the knowledge, skills and techniques learned through training, while operating through realistic role play situations. They will be accompanied by a Field Training Instructor (FTI). The FTI is responsible 
for guiding the trainees through the process. If there appears to be a problem with their ability to meet the objective of the scenario, the FTI will generate statements or questions to get them back on track. Students will be required to bring all scenarios to a logical conclusion. This scenario-based training creates the realism of actual field operations situations.

\section{CONCLUSIONS}

The introduction and implementation of e-FLETC Online Campus in the system of professional training of future US border guard officers reveals significant potential in applying the model of continuous education. Use of this Internet Training Center enables FLETC much wider audience of agents, to approach the learning process with international standards of education and strengthen international links. Studying of USA border guard officers' training experience will enable SBGSU to build border infrastructure, to make more effective system of state border protection, to implement new approaches of personnel training, to improve the legal, educational and material base.

Directions for further investigations are methodology improvement of teaching professional disciplines through the use of foreign experience.

\section{REFERENCES}

1. Border Patrol Jobs. Online U.S. Border Patrol Career and Training Headquarters. (2015). Border Patrol Academy: Courses and Curriculum. Retrieved 02.11.2015 from : http://myborderpatroljob.com/border-patrol-academy.

2. Federal Law Enforcement Training Center. (2015). FLETC History. Retrieved 06.11.2015 from : https://www.fletc.gov/fletc-history.

3. Federal Law Enforcement Resources. (2015). Training Centers and Programs for Federal Law Enforcement Personnel. Retrieved 05.11.2015 from : http://www.federallawenforcement.org.

4. Official Website of the DHS. (2015). Homeland Security Information Network Law Enforcement. Retrieved 03.11.2015 from : http://www.dhs.gov/homeland-securityinformation-network-hsin.

5. Official website of the DHS. (2015). US Customs and Border Protection. Retrieved 04.11.2015 from: http://www.cbp.gov/border-security/along-us-borders.

6. Блощинський, І., Гапонова, В., Яремчук, I. (2006). Військовий переклад [Military Translation]. Хмельницький : НАДПСУ, 440 p. (in Ukrainian).

7. Комкова, Е. (2008). Новый этап американо-канадской интеграции [New Stage of American-Canadian Integration]. США - Канада: экономика, политика, культура [USA - Canada: Economy, Politics, Culture], No 5, pp. 15-30 (in Russian).

8. Кузьмінський, А. (2001). Педагогіка вищої школи [Pedagogy of Higher School]. К. : Знання, 486 p. (in Ukrainian).

9. Некрасов, А. (1998). Пограничный контроль на путях международного сообщения [Border Control at International Routes]. Хабаровск, 295 р. (in Russian).

10. Шаран, Р. (2010). Професійна підготовка магістрів інформаиійних технологій в системі дистаниійної освіти США [Professional Training of IT Masters in the US System of Distance Education]. Thesis for PhD. Тернопіль : ТНПУ ім. В. Гнатюка, 249 p. (in Ukrainian).

11. Шуневич, Б. (2008). Розвиток дистаниійного навчання у вищій школі країн Свропи та Північної Америки [Distance Learning Development in Higher Educational Establishments of European and North-American Countries]. Thesis for a Doctoral Degree. К. : Ін-т вищ. освіти АПН України, 510 p. (in Ukrainian). 